\title{
PENYULUHAN KESEHATAN PERTOLONGAN TERSEDAK UNTUK ORANG AWAM DI ERA PANDEMI COVID-19
}

\author{
Misbah Nurjannah ${ }^{1^{*}}$, Zulmah Astuti ${ }^{2}$ \\ 1-2Universitas Muhammadiyah Kalimantan Timur
}

Email Korespondensi: mn325@umkt.ac.id

\begin{abstract}
ABSTRAK
Tersedak adalah suatu kondisi gawat darurat yang harus segera diberikan pertolongan. Tersedak terjadi karena adanya sumbatan pada jalan napas yang disebabkan oleh makanan maupun benda asing lainnya. Sumbatan ini dapat terjadi parsial maupun total dalam menyumbat jalan napas. Penyumbatan jalan napas ini dapat berakibat pada kematian, karena sumbatan ini akan menyebabkan gangguan pada oksigenasi. Tersedak dapat terjadi pada segala usia. Usia yang paling banyak mengalami kondisi ini adalah usia dibawah 6 tahun dan lansia. Penyuluhan kesehatan ini dilakukan untuk memberikan pemahaman dan pengetahuan keterampilan pada masyarakat awam tentang tersedak, penyebab tersedak, tanda dan gejala tersedak, serta penanganan pada kondisi tersedak yang terjadi pada bayi, anak dan dewasa. Metode penyuluhan kesehatan ini dilakukan secara daring via zoom, dan dibantu oleh mahasiswa yang mendampingi peserta sebagai fasilitator. Penyuluhan kesehatan dihadiri oleh 34 orang peserta, dengan laki-laki 10 orang dan wanita 24 orang. Rentang usia peserta 23 - 64 tahun. Hasil penyuluhan kesehatan ini peserta memahami tentang tersedak, penyebab tersedak, tanda dan gejala tersedak dan dapat melakukan tindakan pertolongan pada kondisi tersedak. Kesimpulan penyuluhan kesehatan yang dilaksanakan meningkatkan pengetahuan dan ketrampilan masyarakat tentang penanganan tersedak dengan meningkat 65,4\%. Saran: perlu upaya peningkatan pengetahuan dan ketrampilan yang berkesinambungan agar masyarakat tetap mengingat cara penanganan yang tepat.
\end{abstract}

Kata Kunci: Tersedak, Penanganan Tersedak, Penyuluhan Kesehatan, Online

\begin{abstract}
Choking is an emergency condition that requires immediate help. Choking occurs due to obstruction of the airway caused by food or other foreign objects. This blockage can be partial or total in obstructing the airway. This airway obstruction can result in death, because this blockage will cause interference with oxygenation. Choking can occur at any age. The ages that most experience this condition are under 6 years of age and the elderly. This health education is carried out to provide understanding and knowledge of skills to the general public about choking, causes of choking, signs and symptoms of choking, as well as handling of choking conditions that occur in infants, children and adults. Methods: This Health education has been carried out online via Zoom and assisted by students who accompany the participants as facilitators. Health
\end{abstract}


education was attended by 34 participants, with 10 men participants and 24 women participants, and age range 23-64 years. Results: This health counseling participants understand about choking, causes, signs and symptoms and can take action to help in choking conditions, and increase 65,4\%. Conclusion: of the health education was to increase the knowledge and skills of the community regarding the handling of choking. Participants are able to provide choking assistance. Suggestions: efforts to increase knowledge and skills on an ongoing basis so that people still remember choking treatment.

Keywords: Choking, assistance in cases of choking, Health Counseling, Online

\section{PENDAHULUAN}

Tersedak adalah tersumbatnya jalan napas akibat benda asing yang tidak bisa keluar, dan sumbatan dapat terjadi sebagian maupun keseluruhan. Tersedak dapat menyebabkan terhalangnya pertukaran udara pada saluran napas (Sancho-Chust, Molina et al. (2020) . Kejadian tersedak ini sering tidak dikenali gejalanya oleh orang lingkungan sekitar korban, karena korban tidak bisa mengungkapkan kondisinya. Kondisi tersedak dapat dikenali setelah korban tiba di pelayanan kesehatan, dan tanda dan gejala yang muncul dapat dikenali oleh petugas kesehatan, akan tetapi pengetahuan masyarakat yang ada disekitar korban belum bisa mengenal tanda dan gejala tersedak secara baik. Sehingga tindakan tidak diberikan dengan segera (Rahayu (2014).

Menurut American Academy of Pediatrics (2010) menjelaskan bahwa Kondisi tersedak paling sering terjadi berada pada usia anak. Usia anak kurang dari 3 tahun merupakan usia yang paling banyak mengalami kondisi tersedak, dan usia lansia berkisar pada usia lebih dari 60 tahun. Angka tertinggi berada pada usia bayi yaitu 140,4 per 100.000 populasi, persentase tersedak pada bayi $30,5 \%$, dan kemtian hampir $65 \%$ terjadi pada usia kurang dari 3 tahun (Husada (2018).

Menurut Salih AM tahun 2016 menjelaskan bahwa tersedak dapat terjadi disegala usia, termasuk lansia. Usia lansia menrupakan usia yang rentan terjadi tersedak, karena menurunnya kemampuan dalam mengunyah makanan. Angka kejadian tersedak cukup banyak pada lansia dan tertinggi kedua setelah usia anak (Ma, Hu et al. (2020).

Tanda dan gejala yang muncul pada anak adanya suara stridor. Ketidakmampuan untuk batuk, sesak dan sianosis penurunan suplai oksigen. Tanda dan gejala yang muncul pada dewasa memegang area leher, gejala lanjutan yang dapat muncul adalah penurunan kemampuan untuk bernapas dan batuk, serta sianosis (Harigustian (2020).

Menurut Pavitt, Swanton et al. (2017) menjelaskan bahwa penyebab tersedak paling sering terjadi karena makanan. Pada usia kurang dari 6 tahun penyebab tersedak dapat terjadi dari makan dan bukan makanan. Penyebab tersering tersedak pada usia ini adalah mainan seperti benda padat seperti bola, kelereng, mainan berbentuk bola, dan mainan yang memiliki diameter yang kecil. Hal ini terjadi karena anak lebih menyukai mainan yang mudah digenggam dan berbentuk kecil. Sedangkan makanan yang paling sering menyebabkan tersedak pada usia anak adalah permen yang keras, permen karet, marshmallow. Jenis makanan permen karet dan jelly bersifat alot dan kenyal, sehingga tidak mudah untuk dikunyah oleh anak. Selain itu bentuk makanan juga memiliki ukuran yang kecil dan hampir sama diameternya dengan jalan napas anak (Saputra, Yulianti et al. (2020). 
Sebagian besar tersedak terjadi pada usia anak-anak maka perlu menggali pengetahuan orang tua terntang tersedak, dan memberikan penyuluhan kesehatan terkait tentang penanganan tersedak pada anak dan dewasa. Penanganan yang diberikan dimulai dari penilaian awal hingga memberikan penanganan tersedak (Travers, Rea et al. (2010).

\section{MASALAH}

Rumusan masalah pada kasus kegawatdaruratan ini adalah: "apakah ada tingkat kejadian tersedak di Samarinda?"

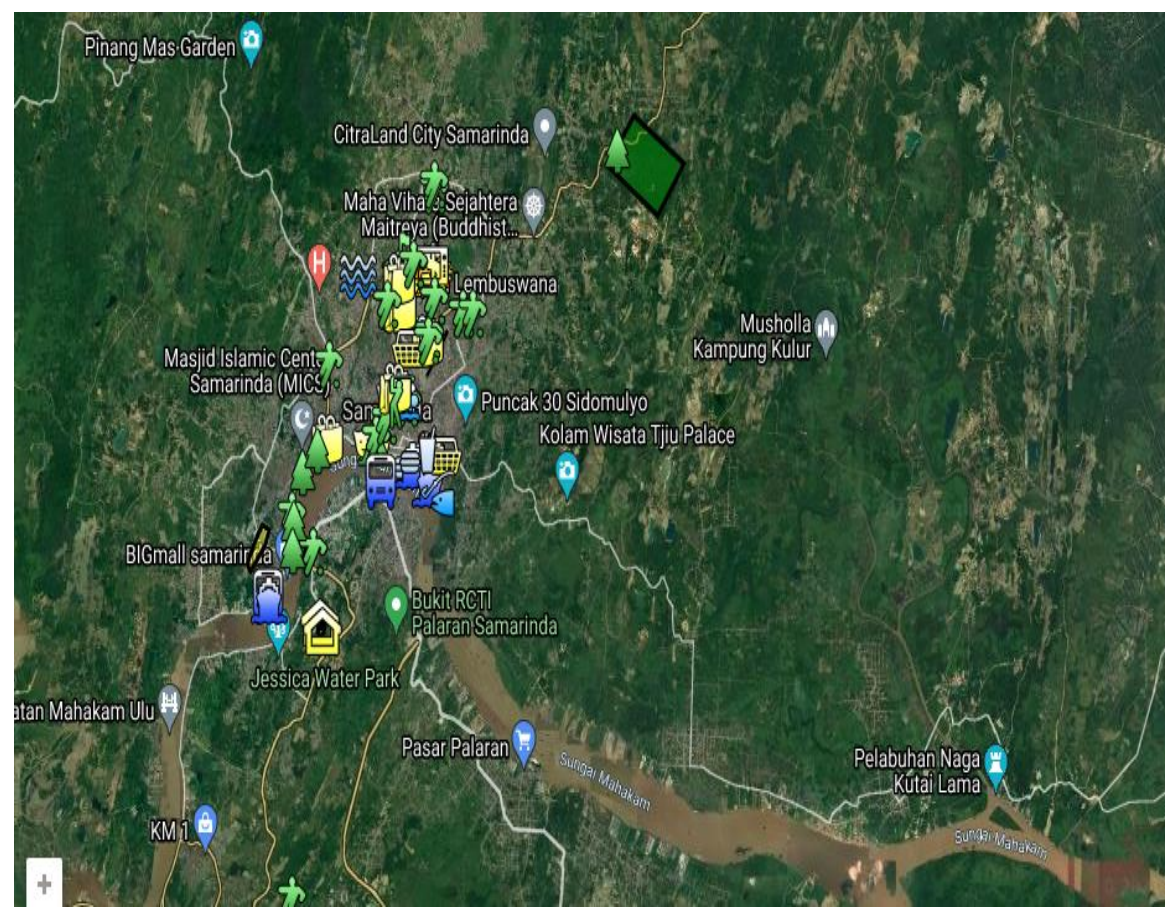

Gambar 1. Lokasi kegiatan Pengabdian Kepada Masyarakat

\section{METODE}

Metode penyuluhan kesehatan ini dilakukan daring via zoom, hal ini dilakukan karena tidak memungkinkan untuk mengumpulkan masyarakat dalam jumlah banyak (lebih dari 10 orang). Peserta penyuluhan merupakan anggota keluarga dari mahasiswa Fakultas Ilmu Keperawatan Program Ners yang sedang melakukan stase Keperawatan Gawat Darurat. Dan selama penyuluhan kesehatan bantuan tersedak dilakukan, peserta didampingi oleh mahasiswa program ners sebagai fasilitator. Dalam pelaksanaan Penyuluhan Kesehatan Pertolongan Tersedak Untuk Orang Awam di Era Pandemi Covid19, ada beberapa tahapan yang dilaksanakan, yaitu:

a. Tahap Pembukaan

Tahap ini merupakan tahap perkenalan antara penyuluh kesehatan dengan masyarakat. Penyuluhan kesehatan dibuka dengan mengucapkan salam, dan memperkenalkan diri dan menyampaikan tujuan dalam pelaksanaan penyuluhan kesehatan yang dilakukan. Selain itu juga menyampaikan kontrak waktu kegiatan yang dilaksanakan. 


\section{b. Tahap Pelaksanaan (Inti)}

Tahap ini adalah tahap pelaksanaan kegiatan penyuluhan kesehatan. Pada tahap ini penjelasan tentang pertolongan tersedak diberikan. Penjelasan pertolongan tersedak meliputi: pengertian tersedak, penyebab, tanda dan gejala, penanganan tersedak pada bayi, anak dan dewasa. Pada tahap ini penyuluh kesehatan mempraktikkan yang kemudian peserta mencoba tindakan dengan dibantu fasilitator masing-masing.

c. Tahap Diskusi

Tahap ini merupakan tahap peserta menberikan pertanyaan terkait dengan materi dan tindakan yang diberikan (dicoba). Diskusi dilakukan untuk meminimalkan kesalahan dalam memberikan tindakan. Diskusi dapat dibantu oleh fasilitator.

d. Tahap Penutup

Tahap ini merupakan tahap akhir dari penyuluhan kesehatan. Tahap ini dapat memberikan pertanyaan untuk mengklarifikasi pada peserta terkait pemahaman yang sudah didapat pada materi. Pada akhir sesi ditutup dengan memberikan reward terima kasih dan salam.

\section{HASIL DAN PEMBAHASAN}

Kegiatan penyuluhan kesehatan bantuan tersedak pada bayi, anak dan dewasa pada keluarga mahasiswa dilakukan oleh anggota keluarga mahasiswa. Mahasiswa sebagai fasilitator yang membantu dan mendampingi anggota keluarga dalam melakukan kegiatan pertolongan tersedak. Korban untuk latihan melakukan pertolongan tersedak adalah anggota keluarga yang lain dengan usia anak dan dewasa. Jumlah peserta dalam penyuluhan kesehatan ini sebanyak 34 orang, dengan jumlah laki-laki sebanyak 10 orang dan wanita sebanyak 24 orang. Rentang usia peserta berkisar 23-64 tahun.

Tahapan penanganan pertolongan tersedak yang dilakukan sesuai dengan SOP yang diajarkan di UMKT. Langkah-langkah pertolongan tersedak pada bayi sebagai berikut:

1. Lihat tanda-tanda tersedak (tidak mampu menangis, suara tidak keluar, nampak sianosis)

2. Telepon bantuan atau meminta orang lain menghubungi bantuan

3. Penolong duduk dikursi atau memajukan salah satu kaki sehingga posisi tubuh seperti setengah duduk dikursi.

4. Penolong meletakkan bayi pada salah satu paha

5. Penolong melakukan back blow (tepukan pada bagian atas punggung bayi). tepukan dilakukan diantara dua skapula.

6. Setelah melakukan 5 kali back blow, tangan penolong melakukan posisi sandwich (menjepit bayi pada kedua tangan) untuk menghindari cedera pada bayi pada saat membalik.

7. Gunakan dua jari ditengah dada yaitu pada bagian bawah garis imaginer putting susu untuk melakukan kompresi dada (Chest trust).

8. Berikan 5 kali kompresi dada (Chest Trust) dengan kecepatan 1 kali kompresi 1 detik

9. Ulangi tindakan langkah nomor 5-8 secara berulang sampai dengan objek sumbatan keluar atau bayi menjadi tidak sadar

10. Setiap 5 kali back blow dan chest trust yang dilakukan, periksa apakah sumbatan sudah keluar atau belum keluar

11. Bila bayi tidak sadar maka mulai lakukan kompresi dada (BHD). 
Langkah-langkah pertolongan tersedak pada anak dan dewasa sebagai berikut:

1. Lihat tanda-tanda tersedak (tidak mampu menangis, suara tidak keluar, nampak sianosis)

2. Telepon bantuan atau meminta orang lain menghubungi bantuan

3. Penolong berdiri atau berlutut dibelakang korban (jika korban anak-anak)

4. Lingkarkan tangan penolong pada area pinggang korban

5. Buat kepalan pada satu tangan yang tidak dominan

6. Letakkan ibu jari disamping luar kepalan tangan

7. Letakkan tangan pada garis tengah sedikit di atas umbilikus dan dibawah tulang dada

8. Genggam kepalan tangan anda dengan tangan yang lain

9. Apabila korban lebih tinggi dari penolong, maka minta korban untuk sedikit membungkukkan badan.

10. Tekan dan dorong ke atas genggaman tangan di abdomen korban dengan cepat

11. Lakukan secara berulang tindakan nomor 10 sampai dengan objek sumbatan keluar atau pasien menjadi tidak sadar

12. Setiap 5 kali heimlich manuver yang dilakukan maka periksa apakah sumbatan sudah keluar atau belum keluar.

13. Bila pasien tidak sadar maka lakukan kompresi dada (BHD).

Capaian dalam kegiatan ini adalah pemahaman dalam memberikan pertolongan tersedak. Pada bagian tahap awal disampaikan bahwa tujuan dalam penyuluhan kesehatan ini, yaitu peserta paham dan mampu melakukan tindakan pertolongan pada korban tersedak. Analisis ini menjelaskan bahwa peserta mampu melakukan tindakan penanganan tersedak.

Berdasarkan pada penyuluhan kesehatan yang dilakukan dapat dijelaskan hasil sebelum dan sesudah penyuluhan kesehatan sebagai berikut:

\begin{tabular}{|c|c|c|c|c|}
\hline No & $\begin{array}{c}\text { Indikator } \\
\text { Capaian }\end{array}$ & $\begin{array}{c}\text { Sebelum } \\
\text { Penyuluhan }\end{array}$ & $\begin{array}{c}\text { Sesudah } \\
\text { Penyuluhan }\end{array}$ & Keterangan \\
\hline 1 & $\begin{array}{l}\text { Peserta } \\
\text { memahami } \\
\text { tentang } \\
\text { pengertian } \\
\text { tersedak }\end{array}$ & $\begin{array}{l}\text { Peserta belum } \\
\text { memahami } \\
\text { tentang } \\
\text { tersedak }\end{array}$ & $\begin{array}{l}\text { Peserta } \\
\text { memahami } \\
\text { tentang } \\
\text { tersedak }\end{array}$ & Tercapai \\
\hline 2 & $\begin{array}{l}\text { Peserta } \\
\text { memahami } \\
\text { tentang } \\
\text { penyebab } \\
\text { tersedak }\end{array}$ & $\begin{array}{l}\text { Peserta belum } \\
\text { memahami } \\
\text { tentang } \\
\text { penyebab } \\
\text { tersedak }\end{array}$ & $\begin{array}{l}\text { Peserta } \\
\text { memahami } \\
\text { tentang } \\
\text { penyebab } \\
\text { tersedak }\end{array}$ & Tercapai \\
\hline 3 & $\begin{array}{l}\text { Peserta } \\
\text { memahami } \\
\text { tentang tanda } \\
\text { dan gejala } \\
\text { tersedak }\end{array}$ & $\begin{array}{l}\text { Peserta belum } \\
\text { memahami } \\
\text { tentang tanda } \\
\text { dan gejala } \\
\text { tersedak }\end{array}$ & $\begin{array}{l}\text { Peserta } \\
\text { memahami } \\
\text { tentang tanda } \\
\text { dan gejala } \\
\text { tersedak }\end{array}$ & Tercapai \\
\hline 4 & $\begin{array}{l}\text { Peserta } \\
\text { memahami dan } \\
\text { mampu } \\
\text { melakukan }\end{array}$ & $\begin{array}{l}\text { Peserta tidak } \\
\text { tahu cara } \\
\text { memberikan } \\
\text { pertolongan }\end{array}$ & $\begin{array}{l}\text { Pesertatahu } \\
\text { cara } \\
\text { memberikan } \\
\text { pertolongan }\end{array}$ & Tercapai \\
\hline
\end{tabular}




$\begin{array}{lll}\text { penanganan } & \text { pada korban } & \text { pada korban } \\ \text { tersedak } & \text { tersedak } & \text { tersedak }\end{array}$

Berdasarkan pada data diatas bahwa peserta memahami tentang tersedak setelah dilakukan penyuluhan kesehatan. Adanya perubahan sebelum dan sesudah penyuluhan kesehatan diberikan. Peserta memhami tentang pengertian tersedak, penyebab dan tanda dan gejala. Hal ini sesuai dengan penjelasan Notoatmodjo (2018) bahwa memahami diartikan sebagai suatu kemampuan menjelaskan secara benar tentang objek yang diketahui, dan dapat menginterpretasi materi tersebut secara benar. Proses memahami ini dapat terjadi setelah diberikan penjelasan atau pembelajaran tentang hal tersebut.

Pada hasil evaluasi tabel di atas dapat dilihat bahwa peserta mampu melakukan pertolongan tersedak setelah dilakukan penyuluhan kesehatan. Peserta mampu mempraktikkan tindakan pertolongan pada anggota keluarga dengan dibantu oleh fasilitator. Hal ini sesuai dengan penjelasan Notoadmojo (2018) menjelaskan bahwa aplikasi diartikan sebagai kemampuan untuk menggunakan materi yang telah dipelajari pada situasi atau kondisi real (sebenarnya).

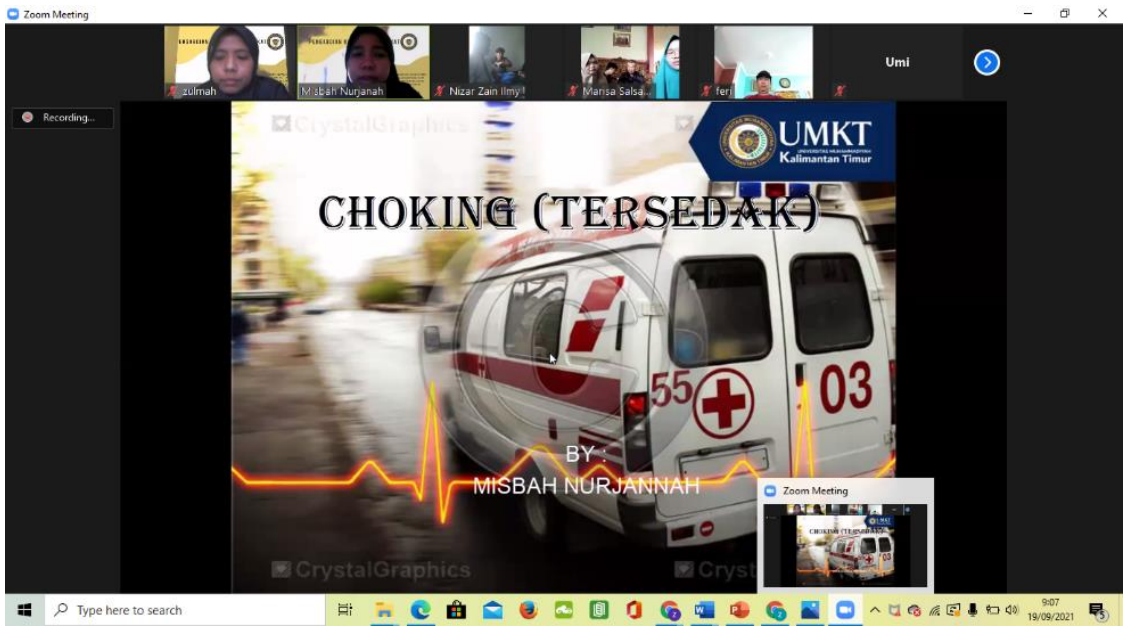

Gambar 2. Foto Kegiatan Pengabdian kepada Masyarakat

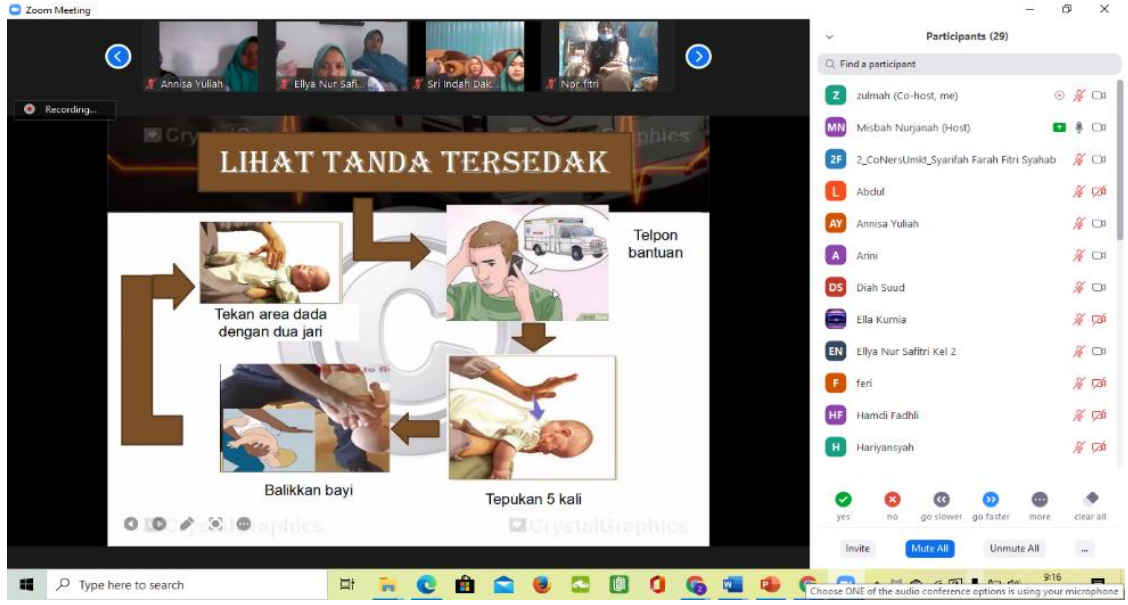

Gambar 3. Foto Kegiatan Pengabdian kepada Masyarakat 


\section{KESIMPULAN}

Kegiatan penyuluhan kesehatan yang telah dilaksanakan ini dapat disimpulkan bahwa adamnya peningkatan pengetahuan dan ketrampilan cara memberikan pertolongan tersedak di masyarakat.

\section{DAFTAR PUSTAKA}

Harigustian, Y. (2020). "Tingkat Pengetahuan Penanganan Tersedak Pada Ibu Yang Memiliki Balita Di Perumahan Graha Sedayu Sejahtera." Jurnal Keperawatan Akper Yky Yogyakarta 12(3): 162-169.

Husada, S. K. (2018). "Gambaran Pengetahuan Ibu Dalam Penanganan Tersedak Asi Pada Bayi Di Posyandu Mawar 2 Dusun Tegalsarituban Gondangrejo Karanganyar."

Ma, W., Et Al. (2020). "Application Of Flexible Fiberoptic Bronchoscopy In The Removal Of Adult Airway Foreign Bodies." Bmc Surgery 20(1): 1-5.

Pavitt, M. J., Et Al. (2017). "Choking On A Foreign Body: A Physiological Study Of The Effectiveness Of Abdominal Thrust Manoeuvres To Increase Thoracic Pressure." Thorax 72(6): 576-578.

Rahayu, R. P. (2014). Pengaruh Pendidikan Kesehatan Terhadap Tingkat Pengetahuan Orangtua Dalam Menangani Anak Tersedak Di Desa Kedungsoka Puloampel Serang Banten, Stikes Jenderal Achmad Yani Yogyakarta.

Sancho-Chust, J. N., Et Al. (2020). "Utility Of Flexible Bronchoscopy For Airway Foreign Bodies Removal In Adults." Journal Of Clinical Medicine 9(5): 1409.

Saputra, T., Et Al. (2020). "Pengabdian Kepada Masyarakat Penangganan Tersedak Pada Orang Dewasa." Jurnal Kreativitas Pengabdian Kepada Masyarakat (Pkm) 3(2): 388-394.

Travers, A. H., Et Al. (2010). "Part 4: Cpr Overview: 2010 American Heart Association Guidelines For Cardiopulmonary Resuscitation And Emergency Cardiovascular Care." Circulation 122(18_Suppl_3): S676-S684. 